\title{
Effect of environmental heavy metals on the expression of detoxification-related genes in honey bee Apis mellifera
}

\author{
Gashawbeza GizAw ${ }^{1}$, YeongHo $\mathrm{KIm}^{2}$, KyungHwan Moon ${ }^{1}$, Jong Bong $\mathrm{CHOI}^{1}$, \\ Young Ho KIM ${ }^{1,2}$, Jong Kyun PARK ${ }^{1,2}$ \\ ${ }^{1}$ Department of Ecological Science, Kyungpook National University, Sangju, Gyeongbuk, Republic of Korea \\ ${ }^{2}$ Department of Applied Biology, Kyungpook National University, Sangju 37224 Gyeongbuk, Republic of Korea
}

Received 4 September 2019 - Revised 2 January 2020 - Accepted 21 February 2020

\begin{abstract}
Air pollutants and agricultural pesticides can be environmental stressors to pollinators. In this study, to investigate the expression of detoxification-related genes and heavy metal concentrations in honey bees and honey possibly exposed to environmental stresses, we collected samples from apiaries located in mountainous, agricultural, and urban areas. Compared with the mountainous and agricultural areas, the mercury and lead concentrations were highest in honey and bees collected from urban areas. In addition, the expression levels of CYP9Q1, CYP9Q2, CYP9Q3, and genes encoding catalase and superoxide dismutase were markedly higher in urban bees than those from agricultural and mountainous areas, discreetly indicating that the notable induction of the detoxification metabolism in urban bees might be because of heavy metal pollutant exposure. Our study suggests that honey bees actively respond to environmental stressors, such as heavy metals derived from urban areas.
\end{abstract}

\section{Apis mellifera / enzyme / detoxification / environmental stressor / heavy metal}

\section{INTRODUCTION}

The honey bee (Apis mellifera L.) plays a major role in sustaining food security and maintaining biodiversity, providing critical pollination services to natural ecosystems and crop production (Leonhardt et al. 2013). Over the last decade, colony collapse disorder (CCD), a syndrome describing the large-scale depletion of honey bee colonies, has been reported worldwide, especially in Europe (Potts et al. 2010) and North America ( $\mathrm{Hu}$ et al. 2017). Some of the major causes of CCD include parasites, pathogens (Alaux et al. 2010; Cornman

Electronic supplementary material The online version of this article (https://doi.org/10.1007/s13592-020-00751-8) contains supplementary material, which is available to authorized users.

Corresponding author:Y. H. Kim, yhkim05@knu.ac.kr; J. K. Park, entopark@knu.ac.kr

Manuscript editor: Klaus Hartfelder et al. 2012), metal and metalloid contaminants (Han et al. 2002), exposure to pesticides (Henry et al. 2012), pathogen-pesticide interactions (Pettis et al. 2012), and interactions between chemical pollutants and natural stressors (Holmstrup et al. 2010).

Anthropogenic activities associated with the accelerated growth of urbanization and industrialization over the past century have created localized and regional pollution problems (Molina and Molina 2004). Exposure to metal and metalloids in polluted areas can impair insect behavior, ultimately, for some insects, reducing species fitness, population numbers, and species diversity (Mogren and Trumble 2010). According to the Agency for Toxic Substances and Disease Registry (ATSDR 2007), arsenic, lead $(\mathrm{Pb})$, cadmium, and mercury $(\mathrm{Hg})$ are some of the common heavy metal pollutants with serious health implications (Gupta et al. 2015).

In insects, including honey bees, the immune and detoxification systems respond quickly to chemical

\section{Springer IDIB INRAC}


and biological stresses (Lemaitre and Hoffmann 2007), and metabolic resistance is the principal mechanism to escape the adverse effects of both natural and synthetic toxins. Cytochrome P450 monooxygenases (P450s) have a fundamental role in metabolic detoxification of pyrethroids, which constitute the majority of commercial insecticides (Mao et al. 2009). The $C Y P 9 Q$ genes contribute to mediating acaricide-tau-fluvalinate and coumaphos-detoxification in honey bees (Mao et al. 2011), while CYP6AS3 is involved in the detoxification of quercetin, a flavonoid present in pollen and numerous floral nectars that constitute the honey bee diet, and a potent enzyme inhibitor (Mao et al. 2009). In addition, antioxidant enzymes mediate the intracellular reactive oxygen species (ROS) balance essential for cell survival. An increase in oxidative stress is associated with the upregulation of antioxidant genes, such as superoxide dismutase $(S O D)$ and catalase $(C A T)$, to prevent ROS-mediated damage (Corona and Robinson 2006).

Considering that urban and agricultural areas are possibly contaminated with metal/metalloid and pesticide pollutants, respectively, an investigation of the expression of detoxification-related genes in honey bees in different environmental situations can aid the understanding of the physiological responses of the honey bees toward different environmental stressors. From this perspective, we collected honey bees from three locations (mountainous, agricultural, and urban) with diverging human activity and interference to compare the expression trends of genes involved in the detoxification mechanism (CYP9Q members) and antioxidant pathway (CAT and $S O D$ ) in honey bees from the various locations. In addition, we measured the $\mathrm{Hg}$ and $\mathrm{Pb}$ concentrations in honey and honey bees, as suitable bioindicators of environmental pollution (Oroian et al. 2016), to distinguish the anthropogenic activities associated with each location.

\section{MATERIALS AND METHODS}

\subsection{Study area and sampling}

The three landscapes (mountainous, agricultural, and urban) were systematically selected. The urban site was located in a large city in South Korea close to an industrial zone and residence area. It has a high human influence/interference and high emission of chemical substances from industries (Figure 1a). The agricultural land site was near farming fields with rice and vegetable production activities (Figure $1 \mathrm{~b}$ ). The mountainous site was surrounded by mountains, with limited agricultural activity and human interference compared with the urban and agricultural areas (Figure 1c). The maps were captured from Google satellite maps and colored with Windows Paint (Windows 10, Microsoft Software, London, UK). Three different colonies of beehives were randomly selected from each apiary site. From each beehive, we collected 20 honey bees and $30 \mathrm{~mL}$ of honey on July 25, 2017. All bee samples are considered to be nurses because we collected honey bees from the hives during the daytime. The collected honey bees and honey were frozen directly with liquid nitrogen and stored at $-70{ }^{\circ} \mathrm{C}$ until RNA extraction and heavy metal analysis.

\subsection{Total RNA preparation and cDNA synthesis}

Considering that the midgut is the major organ involved in detoxification and protection from oxidative stress in insects (Arrese and Soulages 2010), the abdomens were separated from the whole body of three nurses and pooled as a single replication. RNA samples were prepared from three technical replicates. Abdomen samples were completely homogenized with TRI reagent (Molecular Research Center, Inc., Cincinnati, OH), and total RNA was extracted using Direct-zol ${ }^{\mathrm{TM}}$ RNA Miniprep Plus (Zymo Research, Irvine, CA). DNase I digestion occurred during the RNA extraction procedure to eliminate genomic DNA contamination (Moon et al. 2018). The purity and quantity of the extracted RNAs were measured using a SpectraMax ${ }^{\circledR}$ QuickDrop $^{\text {TM }}$ spectrophotometer (Molecular Devices, Sunnyvale, CA).

\subsection{Quantitative reverse transcription PCR}

Sequence information of five genes (SOD1, CAT, CYP9Q1, CYP9Q2 , and CYP9Q3) was obtained from the NCBI database (Table I). Their primers were accurately designed using Oligo Calc software (http://biotools.nubic. 


\section{(a) Urban}

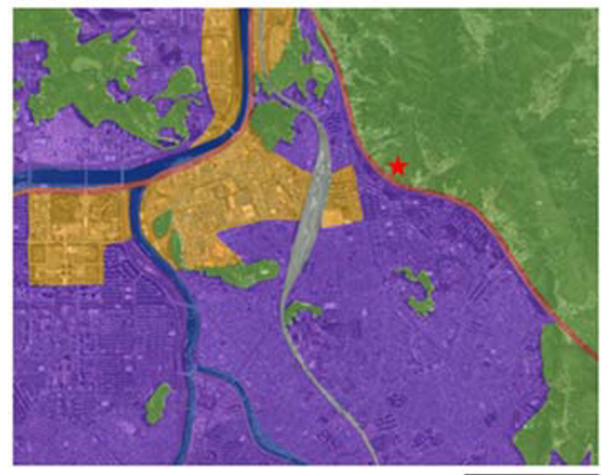

\section{(b) Agriculture}

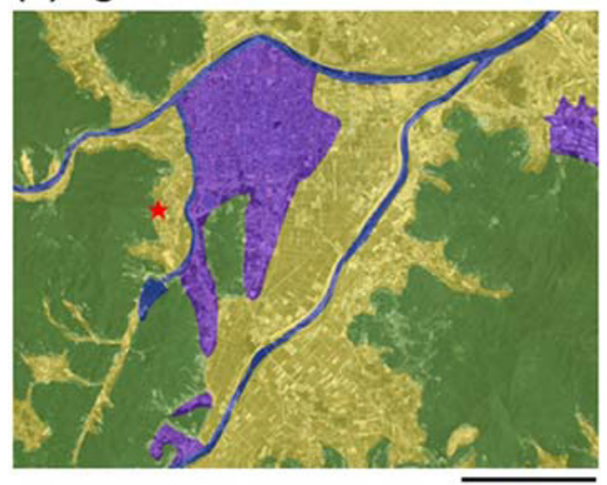

\section{(c) Mountain}

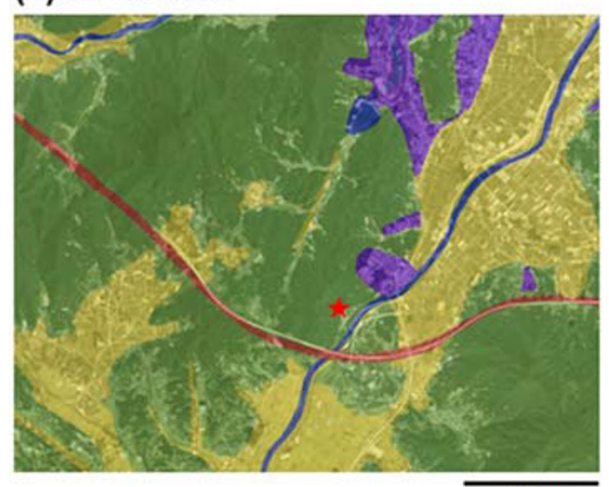

$2 \mathrm{~km}$

northwestern.edu/OligoCalc.html) to ensure similar properties of each primer and amplicon (Table I). GAPDH (glyceraldehyde 3-phosphate dehydrogenase) and RPS18 (ribosomal protein $\mathrm{S} 18)$ were selected as the reference genes to normalize the gene expression levels (Moon et al. 2018). The PCR specificities and amplification efficiency were verified (Table I) before conducting quantitative reverse transcription PCR (qPCR).

To analyze the expression levels of the five target genes in the abdomen of honey bees collected from three different locations, qPCR was performed using RNA-direct ${ }^{\mathrm{TM}}$ SYBR Green Real-time PCR Master Mix (Toyobo, Osaka, Japan). Each sample was analyzed in triplicate (technical replicate) in a total reaction volume of $20 \mu \mathrm{L}$, containing $100 \mathrm{ng}$ of the prepared RNA sample. Quantification cycle $\left(C_{q}\right)$ values of the five target genes and reference genes were obtained from the same sample of each location. The relative expression of genes was normalized against the mean $C_{q}$ values of $G A P D H$ and RPS18 and analyzed by the relative quantification method modified from the original concept of $2^{-}$ $\Delta \Delta C q$ (Pfaffl 2001).

\subsection{Heavy metal concentration in honey and honey bees}

To determine the environmental stressor in each location, we measured the concentration of two heavy metals $(\mathrm{Hg}$ and $\mathrm{Pb})$ in honey bees and honey samples using the Association of Official Analytical Chemists method (AOAC 1990). Accordingly, after adding $\mathrm{HNO}_{3}$ to $10 \mathrm{~g}$ of the sample, the mixture was allowed to stand at room temperature for $12 \mathrm{~h}$ and heated at $100{ }^{\circ} \mathrm{C}$ for at least $24 \mathrm{~h} . \mathrm{HNO}_{3}$ was added again, and the reaction was repeated until the acid was completely evaporated in order to remove the organic matter. Afterward, $20 \mathrm{~mL}$ of $0.2 \mathrm{~N} \mathrm{HNO}_{3}$ solution was added, and the sample solution was re-eluted for $24 \mathrm{~h}$. After filtration through a $0.45-\mu \mathrm{m}$ membrane filter, the solution was adjusted to $50 \mathrm{~mL}$ in a volumetric flask. $\mathrm{Hg}$ and $\mathrm{Pb}$ were analyzed using an inductively coupled plasma optical emission spectrometer (IRIS Intrepid, Thermo Elemental Co., Winsford, UK) at $A_{184.950(482)}$ and 


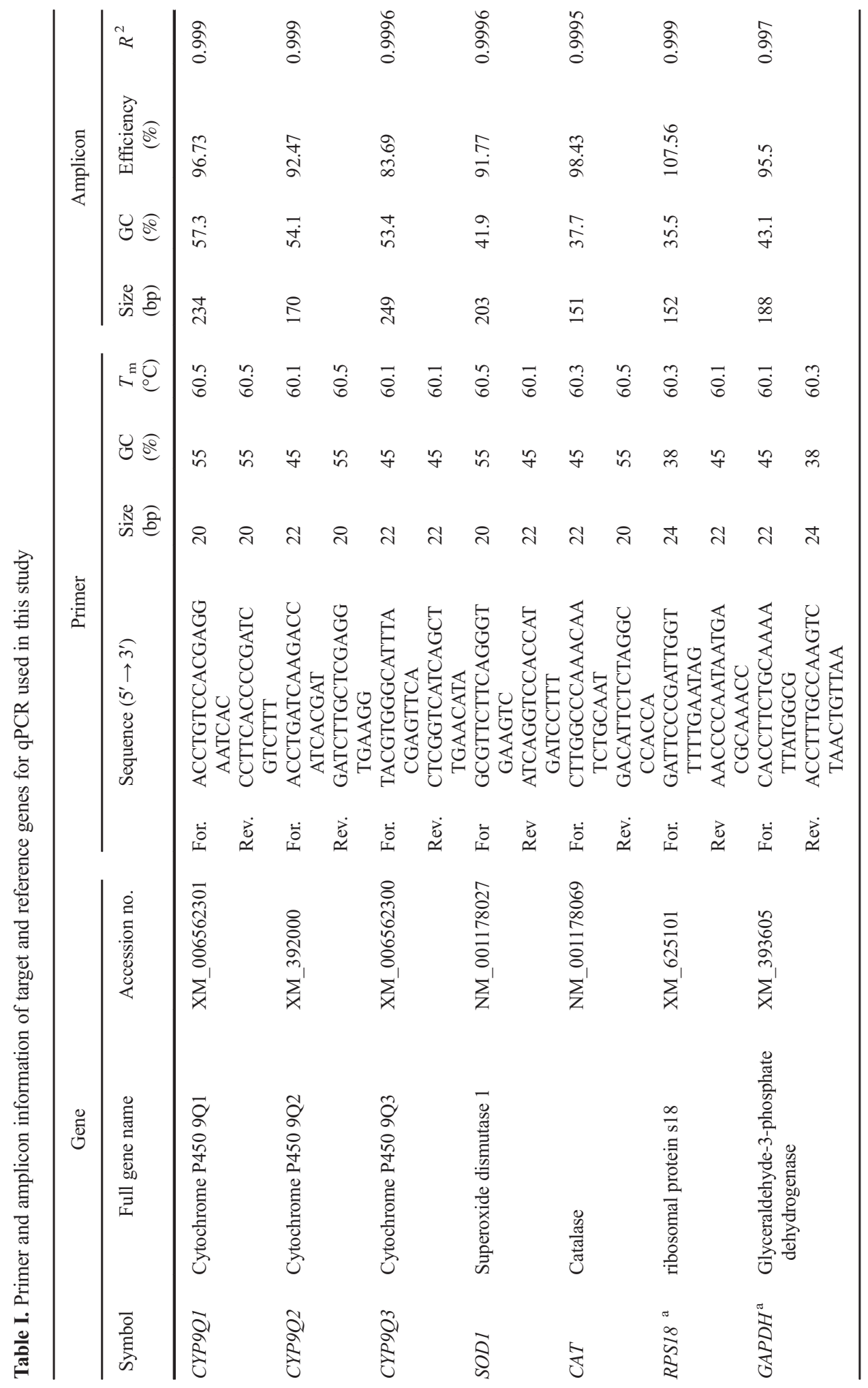


$A_{220.353(453) \text {, respectively, operating at an } \mathrm{RF}}$ power of $1150 \mathrm{~W}$, analysis pump rate of $100 \mathrm{rpm}$, nebulizer pressure of $20 \mathrm{psi}$, and observation height of $15 \mathrm{~mm}$.

\subsection{Statistical analyses}

Data were analyzed using SAS version 9.4 (SAS Institute, Inc., Cary, NC) at the significance level of $P<0.05$. One-way ANOVA, followed by the Tukey-Kramer multiple comparison post hoc test, was performed to compare the expression levels of genes between different locations. Results are given as mean \pm standard error.

\section{RESULTS}

\subsection{Antioxidant protection (SODI and $C A T$ expression)}

In this study, we compared the expression levels of SOD1 and CAT involved in the antioxidant protection processes in the honey bees from three different geographical locations. qPCR revealed that SOD1 and $C A T$ were more abundantly transcribed in urban bee $(P<0.05)$, whereas their expression levels between mountainous and agricultural regions were not statistically different $(P>0.05$; Figure 2$)$. This result implies that honey bees in an urban area might have increased exposure to oxidative stressors compared with those in mountainous and agricultural environments.

\subsection{Detoxification (expression of $C Y P 9 Q$ genes)}

A comparison of the expression levels of the major detoxification genes $(C Y P 9 Q 1, C Y P 9 Q 2$, $C Y P 9 Q 3$ ) showed that the expression levels were dramatically higher in urban bees than bees from mountainous or agricultural regions $(P<0.05$; Figure 3). Urban bees expressed higher $(P<0.05)$ levels of $C Y P 9 Q 1$ (Figure 3a), $C Y P 9 Q^{2}$ (Figure $3 \mathrm{~b}$ ), and $C Y P 9 Q 3$ (Figure 3c), followed by the bees in the agricultural region, which had marginally but not significantly higher expression levels than those from bees located in the
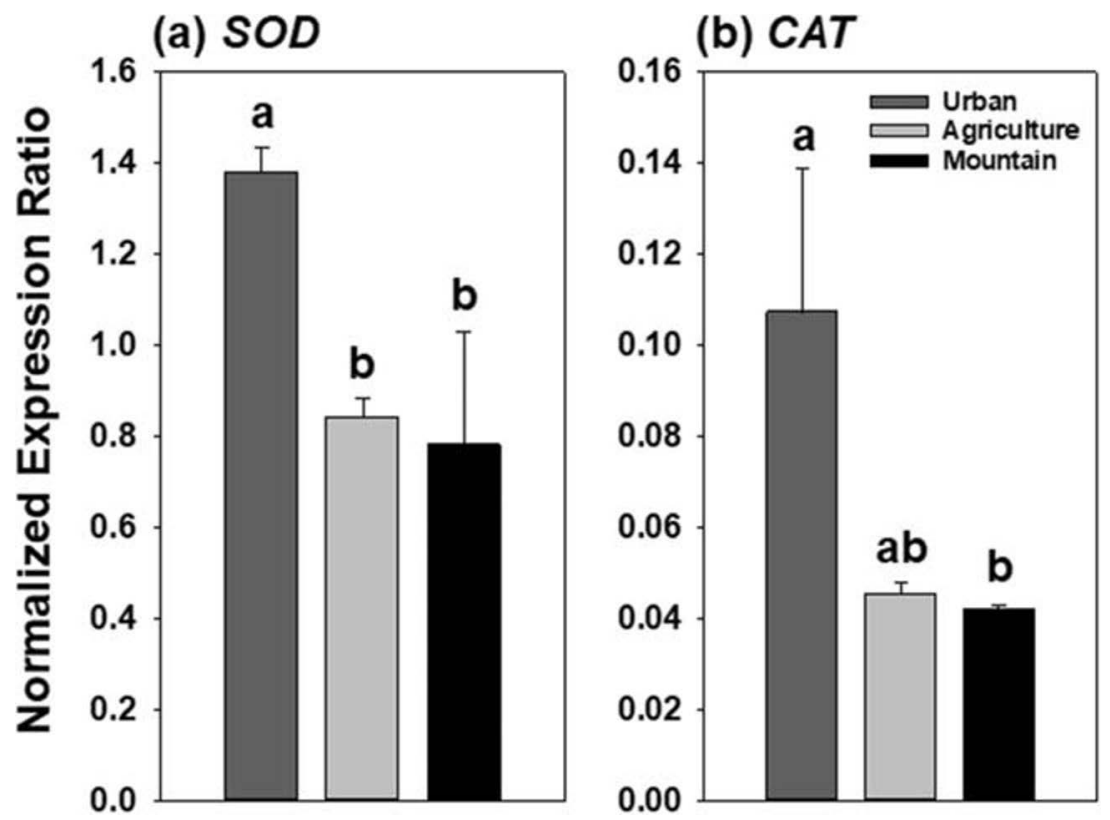

Figure 2. Expression levels of superoxide dismutase $1(S O D 1)$ (a) and catalase $(C A T)$ (b) in the abdomen tissue of honey bees collected from thee different locations: urban, agricultural, and mountainous. The mRNA expression of the genes was quantified and normalized. Vertical bars represent the mean $\pm \mathrm{SE}(n=3)$. Different letters above the bar indicate significant differences at $P<0.05$. 
(a) CYP9Q1

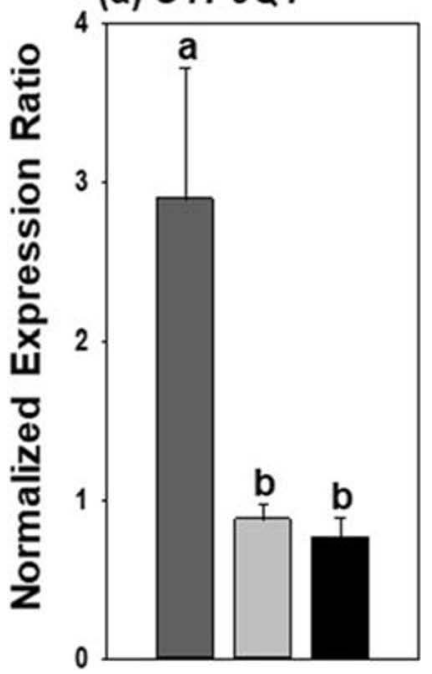

(b) CYP9Q2

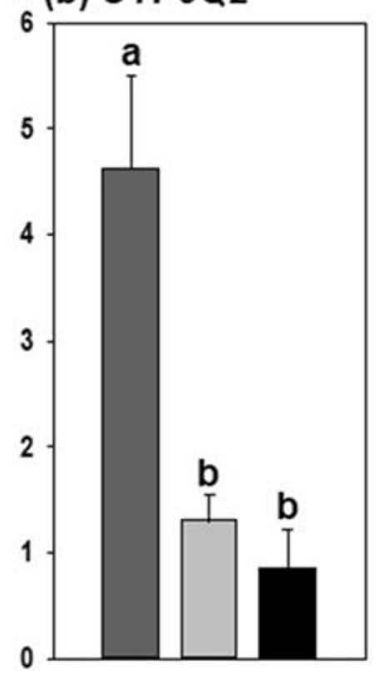

(c) CYP9Q3

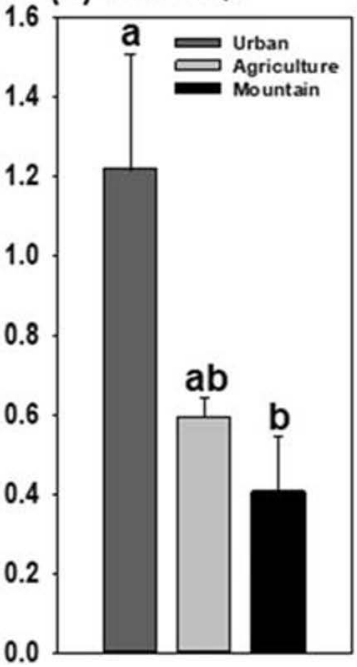

Figure 3. Expression levels of $C Y P 9 Q 1$ (a), CYP9Q2 (b), and CYP9Q3 (c) in the abdomen tissue of honey bees collected from three different locations: urban, agricultural, and mountainous. The mRNA expression of the genes was quantified and normalized. Vertical bars represent the mean $\pm \mathrm{SE}(n=3)$. Different letters above the bar indicate significant differences at $P<0.05$.

mountainous region $(P>0.05)$. The noticeably higher expression level of $C Y P 9 Q$ genes in urban bees was suggestive of honey bee responses to the environmental xenobiotics generated by industrial activity in the city.

\subsection{Heavy metal concentration in honey and honey bees}

The $\mathrm{Hg}$ and $\mathrm{Pb}$ concentrations were measured in honey (Hg: 0.665, 1.009, and 3.249 mg/kg; Pb: $0.130,0.131$, and $0.238 \mathrm{mg} / \mathrm{kg}$; Figure $4 \mathrm{a}$ ) and honey bees (Hg: not detected, and 0.039 and $0.051 \mathrm{mg} / \mathrm{kg}$; Pb: 0.258, 0.363, and $0.489 \mathrm{mg} / \mathrm{kg}$; Figure 4b) collected from mountainous, agricultural, and urban areas, respectively. In all instances, except for $\mathrm{Hg}$ in the honey bees, the urban environment had the highest levels of both heavy metals $(P<0.05)$. There was also a trend of increased concentrations of $\mathrm{Pb}$ and $\mathrm{Hg}$ in agricultural samples (both honey and honey bees) than that in mountainous samples, but this was only significant for $\mathrm{Hg}$ in honey and $\mathrm{Pb}$ in honey bees $(P<0.05)$. According to the provisional tolerable weekly intake (PTWI) value established by a joint WHO/FAO expert consultation, the PTWI $(\mu \mathrm{g} / \mathrm{kg}$ (body weight)/week) of $\mathrm{Hg}$ and $\mathrm{Pb}$ by humans are 5 and $25 \mu \mathrm{g} / \mathrm{kg} /$ week, respectively (WHO/FAO 2015). Considering the weekly amount of honey consumption, the concentrations of $\mathrm{Hg}$ and $\mathrm{Pb}$ detected in the present study seem to be safe for humans.

\section{DISCUSSION}

Contamination of agricultural and urban environments with pesticides and industrial pollutants, respectively (Borrego et al. 2006; Satoh 2006), can expose honey bees to environmental stresses, triggering physiological responses to the stressors. In particular, several industrial activities contribute to air pollution experienced by many urban regions (Borrego et al. 2006). In the present study, we detected higher $\mathrm{Hg}$ and $\mathrm{Pb}$ concentrations in urban samples of both honey and honey bees compared with the corresponding samples from agricultural and mountainous areas (Figure 4). Several previous studies detected various amounts of heavy metals in different geographical locations and areas associated with anthropogenic development. Compared with the $\mathrm{Pb}$ concentration detected in honey bees from mountainous $(0.258$ 

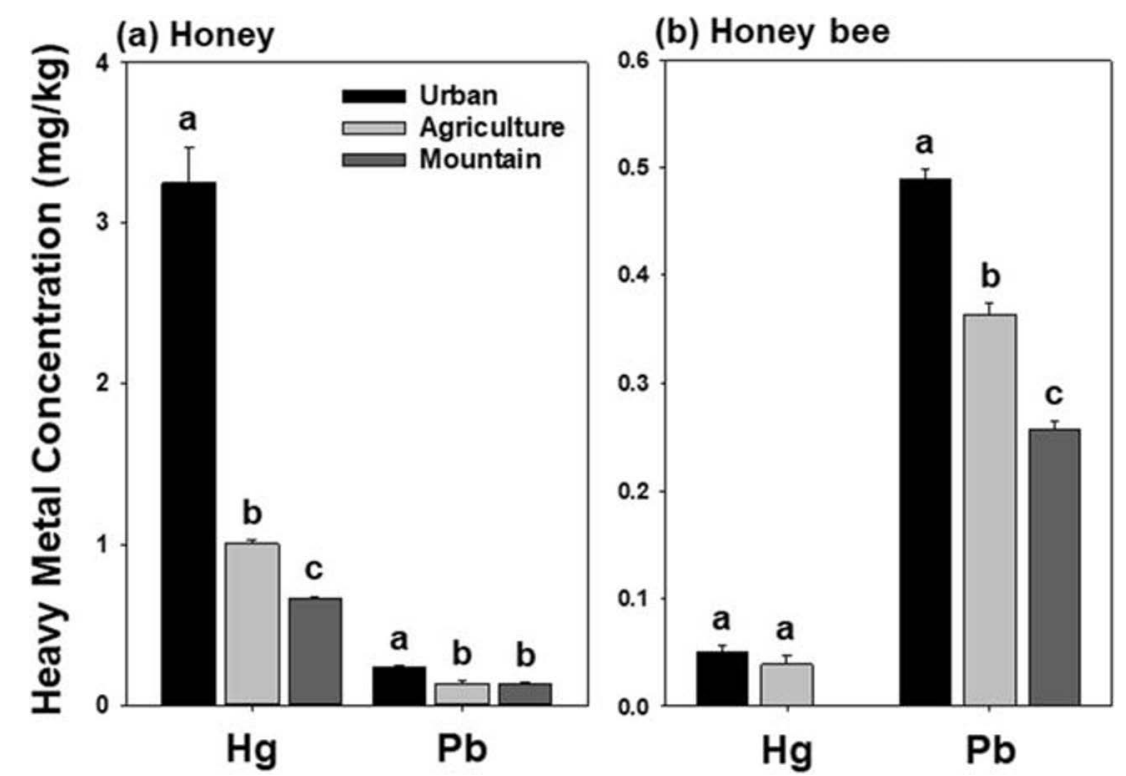

Figure 4. Concentrations of heavy metal ( $\mathrm{mg} / \mathrm{kg}$ ) residues in honey (a) and honey bee (b) samples collected from apiaries in different locations: urban, agricultural, and mountainous. (Hg, mercury; $\mathrm{Pb}$, lead). Vertical bars represent the mean $\pm \mathrm{SE}(n=3)$. Different letters above the bar indicate significant differences at $P<0.05$.

$\mathrm{mg} / \mathrm{kg})$ and agricultural $(0.363 \mathrm{mg} / \mathrm{kg})$ areas in our study (Figure 4b), Conti and Botrè (2001) found a higher mean value of $\mathrm{Pb}(0.52-$ $1.00 \mathrm{mg} / \mathrm{kg}$ ), while Porrini et al. (2002) showed a similar amount of $\mathrm{Pb}$ in a national park $(0.15$ $0.55 \mathrm{mg} / \mathrm{kg}$ ). In urban bees, we detected $0.489 \mathrm{~kg} /$ $\mathrm{ml} \mathrm{Pb}$ (Figure 4b), while Roman (2010) measured $0.64-1.25 \mathrm{mg} / \mathrm{kg} \mathrm{Pb}$. In addition, Velemínský et al. (1990) noted a high concentration of $\mathrm{Hg}$ $(3.68-9.28 \mathrm{mg} / \mathrm{kg})$ in bees collected from industrial areas relative to that indicated in our study $(0.051 \mathrm{mg} / \mathrm{kg}$; Figure $4 \mathrm{~b})$. Contradictory to the low amounts of $\mathrm{Hg}(0.001-0.145 \mathrm{mg} / \mathrm{kg})$ commonly reported in honey sampled from mountainous areas, villages, and cities (Bilandžić et al. 2012; Carrero et al. 2013), the concentration range of $\mathrm{Hg}$ in our honey samples was $0.665-3.249 \mathrm{~kg} /$ $\mathrm{mg}$ (Figure 4a). However, the maximal $3.249 \mathrm{mg} / \mathrm{kg}$ of $\mathrm{Hg}$ we detected in our honey samples is comparable to the mean $\mathrm{Hg}$ content of $3.030 \mathrm{mg} / \mathrm{kg}$ in honey collected from Iran (Akbari et al. 2012). Data obtained from the literature and our study infer that honey and honey bees are environmentally exposed to heavy metals originating from industrial activity. In this study, only $1.4 \mathrm{~km}$ separated the apiary site from the industrial zone in the urban area (Figure 1a), and there were two large highways in front of the apiary site. This scenario possibly contributed to the heavy metal contamination in the urban environment, which could explain the higher $\mathrm{Hg}$ and $\mathrm{Pb}$ concentrations in honey from the urban area relative to the other two locations (Figure 4a). It should also be noted that honey bees are sequentially exposed to heavy metal-contaminated honey in the beehive, supporting the predominant detection of $\mathrm{Hg}$ and $\mathrm{Pb}$ in the urban honey bees, too (Figure 4b). Although heavy metal concentrations in the agricultural region were less than those in the urban area, they were generally higher than those in the mountainous region (Figure 4), indicating that there must be a pollutant source in the agricultural field studied. Fertilizers, pesticides, and organic manure are the main sources of heavy metals in agricultural soils (Nicholson et al. 2003; Mirsal 2004; Zhang 2006), as supported by our results, showing a trend of higher $\mathrm{Hg}$ and $\mathrm{Pb}$ concentrations in the agricultural region than that in the mountainous area (Figure4). Moreover, $\mathrm{Hg}$ was not detected in honey bees from the mountainous region, indicating that the mountain environment remains relatively low in pollutant 
contamination. In the comparison of heavy metal concentrations between honey and honey bees (Figure 4), Hg concentrations were higher in honey than those in honey bees, whereas $\mathrm{Pb}$ showed the opposite trend. In humans, the in vivo halflives of $\mathrm{Hg}$ and $\mathrm{Pb}$ differ because of distinctly different tissues and pathways mainly contributing to heavy metal metabolism (reviewed by Brodkin et al. 2007). Although the pathways of $\mathrm{Hg}$ and $\mathrm{Pb}$ metabolism in honey bees have not yet been fully elucidated, the differences between the amounts of $\mathrm{Hg}$ and $\mathrm{Pb}$ detected in honey and the honey bees could imply that this insect has distinct mechanisms of efficiency of absorption and excretion of these two heavy metals.

According to the expression levels of SOD1, $C A T$, and the three $C Y P 9 Q$ members, honey bees physiologically respond to pollutants (Figure 2 and Figure 3) because their expression trends between different apiary sites were highly correlated with the differences in $\mathrm{Hg}$ and $\mathrm{Pb}$ concentrations among the three areas $\left(R^{2}>0.95\right.$; Fig. S1). Considering that SOD and CAT are representative antioxidative enzymes, urban bees may be exposed to oxidative stresses. Heavy metals are known to induce oxidative stress (Puppel et al. 2015) that is accompanied by an upregulation of antioxidant enzymes, such as SOD and CAT (Corona and Robinson 2006). Previous work suggested CAT activity as a biomarker of exposure to oxidative stress because of its key role in combating ROS in honey bees (Mamidala et al. 2011). This enzyme contributes to antioxidant protection (Collins et al. 2004), and was elevated in A. mellifera exposed to xenobiotic compounds in a laboratory (Badiou-Bénéteau et al., 2012). There were equally higher expression levels of antioxidant enzyme genes, such as SOD1 and CAT, in honey bees collected from urban and industrial regions in which the $\mathrm{Pb}$ concentration in bees was also higher relative to that in bees from mountainous regions, suggesting adaptation of honey bees to oxidative stress (Nikolić et al. 2015). These earlier studies support that the induction of SOD1 and CAT in the present study is a physiological response of honey bees exposed to environmental pollutants, including $\mathrm{Hg}$ and $\mathrm{Pb}$, in the urban area (Figures 2 and 4). Besides SOD1 and $C A T$, three $C Y P 9 Q$ genes were highly induced in the bees from the urban area when compared with the mountainous and agricultural regions (Figure 3). P450s are associated with environmental stressors, catalyzing diverse reactions that contribute to the detoxification of natural and synthetic xenobiotics in insects (Feyereisen 1999). The CYP450 genes have a functional role in enhancing tolerance to environmental stress in a range of organisms (Guttikonda et al. 2010) and have been indicated as potential biomarkers of pollution ( $\check{S}$ iroká and Drastichová 2004). In Apis cerana, CYP450 genes were induced by several stresses, including heavy metals (Zhang et al. 2018). In this context, the strong environmental effect of the urban area on the expression level of the target genes (CYP9Q1, CYP9Q2, and CYP9Q3) observed in this study could be caused by pollutants, including heavy metals, emitted from the industries. While it suggests that heavy metals are contributory stress factors in the urban area, this remains to be verified, and further studies are required to determine whether heavy metals promote a negative effect on the urban bees.

It is well recognized that $C Y P$ genes, including $C Y P 9 Q 1, C Y P 9 Q 2$, and $C Y P 9 Q 3$, contribute to pesticide detoxification in honey bees (De Smet et al. 2017), and insecticides can cause oxidative stress, thereby increasing the abundance of antioxidants (Weirich et al. 2002). On this basis, we expected higher expression levels of the three CYP genes in the agricultural area induced by exposure to high concentrations of pesticides because of a high frequency of pesticide application. In contrast to our expectation, the expression levels of the $C Y P 9 Q$ genes were much lower in the bees from this region when compared with those in the urban area (Figures 2 and 3), implying that heavy metals mostly act as environmental stresses and induce the genes involved in detoxification mechanisms in the honey bees.

In summary, we detected high concentrations of the heavy metals $\mathrm{Hg}$ and $\mathrm{Pb}$ (Figure 4), and greater expression levels of detoxification-related genes, SOD1, CAT, CYP9Q1, CYP9Q2, and $C Y P 9 Q 3$ (Figures 2 and 3), in the bees and honey samples from the urban area compared with those in the agricultural and mountainous areas. Furthermore, the gene expression patterns were positively correlated with the concentration of heavy 
metals (Fig. S1) in all three environments, suggesting a physiological response of honey bees to environmental stressors, which could be associated with differences in land use in the urban area. Global environmental pollution is increasing because of continuous and intense industrial and technological development in the world, with toxic metals regarded as one of the major harmful pollutants (Alley et al. 1998). Honey bees have been considered to be excellent bioindicators of heavy metals in the environment (Zarić et al. 2016), as also observed in this study. However, a broad range of studies investigating the correlation between various environmental stresses and the expression trends of detoxification-related genes is required to generalize the physiological response of honey bees toward environmental stresses, and honey bees as bioindicators.

\section{GENERAL SUMMARY}

Environmental stressors, including parasites, pathogens, and exposure to pesticides, metals, and metalloid pollutants, have been implicated as detrimental to cellular homeostasis and physiological function, and as potential causes of CCD. These factors alter both the detoxification gene expression pathways and immune responses in honey bees. To investigate the expression of detoxificationrelated genes in honey bees possibly exposed to environmental stresses, we collected honey bees from apiaries located in mountainous, agricultural, and urban (with industrial zone) areas and compared the expression trends of genes involved in the detoxification mechanism $(C Y P 9 Q$ members) and antioxidant pathway (CAT and $S O D 1$ ) in honey bees from the three locations. In addition, we collected honey samples from the same areas, and measured the $\mathrm{Hg}$ and $\mathrm{Pb}$ contents in honey and honey bees to distinguish anthropogenic activities in each location.

For gene analysis, RNA samples were prepared from the abdomen, and qPCR was performed. For heavy metal analysis, the $\mathrm{Hg}$ and $\mathrm{Pb}$ concentrations in honey bees and honey samples were measured using the AOAC method. Data were statistically analyzed to compare the expression levels of genes and the concentration of heavy metals among the locations.

In this study, qPCR revealed dramatically increased expression levels of SOD1 and CAT in urban bees (Figure 2), indicating a greater exposure of the honey bees to oxidative stressors in the urban areas compared with the other two locations. Similarly, the $C Y P 9 Q 1, C Y P 9 Q 2$, and $C Y P 9 Q 3$ levels were increased noticeably in urban bees relative to their mountainous and agricultural land counterparts (Figure 3), suggesting that honey bee responses to the environmental xenobiotics resulted from industrial activity in the urban area. In addition, heavy metal analysis showed a marked increase in the $\mathrm{Hg}$ and $\mathrm{Pb}$ concentrations in the honey sample, and in the level of $\mathrm{Pb}$ in honey bees sampled from the urban area (Figure 4), inferring that urban areas expose honey bees to greater pollution by heavy metals in comparison with mountainous and agricultural regions. This implication was supported by a strong and positive correlation of the CYP9Q1-3, $S O D 1$, and $C A T$ expression patterns with the concentration of heavy metals (Fig. S1).

Heavy metals induce oxidative stress, and antioxidant enzymes, such as SOD and CAT, regulate the intracellular ROS balance. Likewise, the CYP9Q subfamily has been reported to catalyze various reactions that contribute to the detoxification of natural and synthetic xenobiotics in insects. Therefore, the strong environmental effect of the urban area on the transcript accumulation of $C Y P 9 Q 1, C Y P 9 Q 2, C Y P 9 Q 3, C A T$, and SOD1 observed in this study could be caused by pollutants, including heavy metals, that were emitted from the industries in the urban area. However, it remains to be verified and warrants further investigation.

\section{AUTHORS' CONTRIBUTION}

GG, YHK, and JKP conceived this research and designed experiments; GG, KM, YK, and JBC performed experiments and analysis; GG and YHK wrote the paper. All authors read and approved the final manuscript.

\section{FUNDING INFORMATION}

This study was supported by the Basic Science Research Program through the National Research Foundation of Korea (NRF) funded by the Ministry of Science, ICT \& Future Planning (2017R1C1B2008699).

\section{COMPLIANCE WITH ETHICAL STANDARDS}

Conflict of interest The authors declare that they have no conflict of interest. 
Effet des métaux lourds de l'environnement sur l'expression des gènes liés à la détoxification chez l'abeille, Apis mellifera.

\section{Apis mellifera / enzyme / détoxification / facteur de stress environnemental / métal lourd.}

Der Effekt von Schwermetallbelastungen auf die Expression von Detox-Genen bei der Honigbiene Apis mellifera.

\section{Apis mellifera / Enzyme/ Detoxifikation/ Umweltstressoren/ Schwermetall .}

\section{REFERENCES}

Akbari B., Gharanfoli F., Khayyat M.H., Khashyarmanesh Z., Rezaee R., Karimi G. (2012) Determination of heavy metals in different honey brands from Iranian markets. Food Addit. Contam. B 5 (2), 105-111

Alaux C., Brunet J.L., Dussaubat C., Mondet F., Tchamitchan S., Cousin M., Brillard J., Baldy A., Belzunces L.P., Conte Y.L. (2010) Interactions between Nosema microspores and a neonicotinoid weaken honeybees (Apis mellifera ). Env. Microbiol. 12 (3), 774-782

Alley E.R., Stevens L.B., Cleland W.L. (1998) Air Quality Control Handbook. McGraw-Hill, New York

AOAC (1990) Official Methods of Analysis, 15th edn. Association of Official Analytical Chemists, Washington, $\mathrm{DC}$

Arrese E.L., Soulages J.L. (2010) Insect fat body: energy, metabolism, and regulation. Annu. Rev. Entomol. 55, 207-225

ATSDR (2007) Draft toxicological profile for cadmium. Agency for Toxic Substances and Disease Registry. Atlanta, GA

Badiou-Bénéteau A., Carvalho S.M., Brunet J.L., Carvalho G.A., Buleté A., Giroud B., Belzunces L.P. (2012) Development of biomarkers of exposure to xenobiotics in the honey bee Apis mellifera: application to the systemic insecticide thiamethoxam. Ecotoxicol. Environ. Saf. 82, 22-31

Bilandžić N., Đokić M., Sedak M., Varenina I., Kolanović B.S., Končurat A., Šimić B., Rudan N. (2012) Content of five trace elements in different honey types from Koprivnica-Križevci County. Slov. Vet. Res. 49(4), 167-175

Borrego C., Martins H., Tchepel O., Salmim L., Monteiro A., Miranda A.I. (2006) How urban structure can affect city sustainability from an air quality perspective. Environ. Model. Softw. 21 (4), 461-467
Brodkin E., Copes R., Mattman A., Kennedy J., Kling R., Yassi A. (2007) Lead and mercury exposures: interpretation and action. Can. Med. Assoc. J. 176 (1), 59-63

Carrero, P., Rondón, C., Saavedra, A. R., Vit, P. (2013) A study of $\mathrm{Hg}$ and $\mathrm{Pb}$ content in meliponine honey (Apidae: Meliponini), in: Vit, P. and Roubik, D. W. (Eds.), Stingless bees process honey and pollen in cerumen pots. Universidad de Los Andes, Venezuela, Chapter 8 [online] http://www.saber.ula. ve/bitstream/handle/123456789/36995/8 hg pbcontent.pdf? sequence $=1$ \&isAllowed $=y$ (accessed on 25 Aug 19)

Collins A.M., Williams V., Evans J.D. (2004) Sperm storage and antioxidative enzyme expression in the honey bee, Apis mellifera . Insect Mol. Biol. 13 (2), 141-146

Conti M.E., Botrè F. (2001) Honeybees and their products as potential bioindicators of heavy metals contamination. Environ. Monit. Assess. 69 (3), 267-282

Cornman R.S., Tarpy D.R., Chen Y., Jeffreys L., Lopez D., Pettis J.S., van Engelsdorp D., Evans J.D. (2012) Pathogen webs in collapsing honey bee colonies. PLoS One 7 (8), e43562

Corona M., Robinson G.E. (2006) Genes of the antioxidant system of the honey bee: annotation and phylogeny. Insect Mol. Biol. 15(3), 687-701

De Smet L., Hatjina F., Ioannidis P., Hamamtzoglou A., Schoonvaere K., Francis F., Meeus I., Smagghe G., de Graaf D.C. (2017) Stress indicator gene expression profiles, colony dynamics and tissue development of honey bees exposed to sub-lethal doses of imidacloprid in laboratory and field experiments. PLoS One 12 (2), e0171529

Feyereisen R. (1999) Insect P450 enzymes. Annu. Rev. Entomol. 44, 507-533

Gupta V.K., Singh S., Agrawal A., Siddiqi N.J., Sharma B. (2015) Phytochemicals mediated remediation of neurotoxicity induced by heavy metals. Biochem. Res. Int. $\mathbf{2 0 1 5}, 534769$

Guttikonda S.K., Trupti J., Bisht N.C., Chen H., An Y.Q.C., Pandey S., Xu D., Yu O. (2010) Whole genome coexpression analysis of soybean cytochrome P450 genes identifies nodulation-specific P450 monooxygenases. BMC Plant Biol. 10, 243

Han F.X., Banin A., Su Y., Monts D.L., Plodinec J.M., Kingery W.L., Triplett G.E. (2002) Industrial age anthropogenic inputs of heavy metals into the pedosphere. Naturwissenschaften 89(11), 497-504

Henry M., Béguin M., Requier F., Rollin O., Odoux J.F., Aupinel P., Aptel J., Tchamitchian S., Decourtye A. (2012) A common pesticide decreases foraging success and survival in honey bees. Science 336 (6079), 348-350

Holmstrup M., Bindesbøl A.M., Oostingh G.J., Duschl A., Scheil V., Köhler H.R., Loureiro S., Soares A.M., Ferreira A.L., Kienle C., Gerhardt A., Laskowski R., Kramarz P.E., Bayley M., Svendsen C., Spurgeon D.J. (2010) Interactions between effects of environmental chemicals and natural stressors: a review. Sci. Total Environ. 408(18), 3746-3762 
Hu Y.T., Wu T.C., Yang E.C., Wu P.C., Lin P.T., Wu Y.L. (2017) Regulation of genes related to immune signaling and detoxification in Apis mellifera by an inhibitor of histone deacetylation. Sci. Rep. 7, 41255

Lemaitre B., Hoffmann J. (2007) The host defense of Drosophila melanogaster. Annu. Rev. Immunol. 25, 697-743

Leonhardt S.D., Gallai N., Garibaldi L.A., Kuhlmann M., Klein A.M. (2013) Economic gain, stability of pollination and bee diversity decrease from southern to northern Europe. Basic Appl. Ecol. 14 (6), 461-471

Mamidala P., Jones S.C., Mittapalli O. (2011) Metabolic resistance in bed bugs. Insects 2 (1), 36-48

Mao W., Rupasinghe S.G., Johnson R.M., Zangerl A.R., Schuler M.A., Berenbaum M.R. (2009) Quercetinmetabolizing CYP6AS enzymes of the pollinator Apis mellifera (Hymenoptera: Apidae). Comp. Biochem. Physiol. B 154 (4), 427-434

Mao W., Schuler M.A., Berenbaum M.R. (2011) CYP9Qmediated detoxification of acaricides in the honey bee (Apis mellifera). Proc. Natl. Acad. Sci. 108(31), 12657-12662

Mirsal A.I. (2004) Soil pollution. Origin, monitoring \& remediation. Springer-Verlag, New York

Mogren C.L., Trumble J.T. (2010) The impacts of metals and metalloids on insect behavior. Entomol. Exp. Appl. 135 (1), 1-17

Molina M.J., Molina L.T. (2004) Megacities and atmospheric pollution. J. Air Waste Manage. Assoc. 54 (6), 644-680

Moon K., Lee S.H., Kim Y.H. (2018) Evaluation of reference genes for quantitative real-time PCR to investigate seasonal and labor-specific expression profiles of the honey bee abdomen. J. Asia Pac. Entomol. 21 (4), 1350-1358

Nicholson F.A., Smith S.R., Alloway B.J., Carlton-Smith C., Chambers B.J. (2003) An inventory of heavy metals inputs to agricultural soils in England and Wales. Sci. Total Environ. 311 (1-3), 205-219

Nikolić T.V., Purać J., Orčić S., Kojić D., Vujanović D., Stanimirović Z., Gržetić I., Llijević K., Šikoparija B., Blagojević D.P. (2015) Environmental effects on superoxide dismutase and catalase activity and expression in honey bee. Arch. Insect Biochem. Physiol. 90 (4), 181-194

Oroian M., Prisacaru A., Hretcanu E.C., Stroe S.G., Leahu A., Buculei A. (2016) Heavy metals profile in honey as a potential indicator of botanical and geographical origin. Int. J. Food Prop. 19 (8), 1825-1836

Pettis J.S., vanEngelsdorp D., Johnson J., Dively G. (2012) Pesticide exposure in honey bees results in increased levels of the gut pathogen Nosema. Naturwissenschaften 99 (2), 153-158

Pfaffl M.W. (2001) A new mathematical model for relative quantification in real-time RT-PCR. Nucleic Acids Res. 29 (9), e45
Porrini C., Ghini S., Girotti S., Sabatini A.G., Gattavecchia E., Celli G. (2002) Use of honey bees as bioindicators of environmental pollution in Italy. In Devillers J., Pham-Delègue M.H. (Eds.), Honey bees: estimating the environmental impact of chemicals (pp. 186-247). Taylor \& Francis, New York

Potts S.G., Roberts S.P.M., Dean R., Marris G., Brown M.A., Jones R., Neumann P., Settele J. (2010) Declines of managed honey bees and beekeepers in Europe. J. Apic. Res. 49 (1), 15-22

Puppel K., Kapusta A., Kuczyńska B. (2015) The etiology of oxidative stress in the various species of animals, a review. J. Sci. Food Agric. 95 (11), 2179-2184

Roman A. (2010) Levels of copper, selenium, lead, and cadmium in forager bees. Pol. J. Environ. Stud. 19(3), 663-669

Satoh T. (2006) Global epidemiology of organophosphate and carbamate poisonings. In Gupta R.C. (Ed.), Toxicology of organophosphate \& carbamate compounds, 1st edn (pp. 89-100). Elsevier Academic Press, Burlington

Široká Z., Drastichová J. (2004) Biochemical markers of aquatic environment contamination - cytochrome $\mathrm{P} 450$ in fish. A review. Acta Vet. Brno 73 (1), 123-132

Velemínský M., Láznička P., Starý P. (1990) Honeybees (Apis mellifera) as environmental monitors of heavy metals in Czechoslovakia. Acta Entomol. Bohemoslov. 87, 37-44

Weirich G.F., Collins A.M., Williams V.P. (2002) Antioxidant enzymes in the honey bee, Apis mellifera. Apidologie 33 (1), 3-14

WHO/FAO (2015) General standard for contaminants and toxins in food and feed (CODEX STAN 193-1995). In Codex Alimentarius (pp. 42-47). Codex Alimentarius Commission, Rome

Zarić N.M., Ilijević K., Stanisavljević L., Gržetić I. (2016) Metal concentrations around thermal power plants, rural and urban areas using honeybees (Apis mellifera L.) as bioindicators. Int. J. Environ. Sci. Technol. 13 (2), 413-422

Zhang C. (2006) Using multivariate analyses and GIS to identify pollutants and their spatial patterns in urban soils in Galway, Ireland. Environ. Pollut. 142 (3), 501511

Zhang W., Chen W., Li Z., Ma L., Yu J., Wang H., Liu Z., $\mathrm{Xu}$ B. (2018) Identification and characterization of three new cytochrome P450 genes and the use of RNA interference to evaluate their roles in antioxidant defense in Apis cerana cerana Fabricius. Front. Physiol. 9,1608

Publisher's note Springer Nature remains neutral with regard to jurisdictional claims in published maps and institutional affiliations. 